\title{
O CORPO DO PATRIARCA: UMA ETNOGRAFIA DO SILENNCIO, DA MORTE E DA AUSÊNCIA
}

Vítor Queiroz ${ }^{1}$

${ }^{1}$ Universidade Estadual de Campinas, SP, Brasil

\section{Introdução - Catando folhas}

Ewé pẹe pẹ àni tó pe ewé

pele pe àni tó pe

Làkàkà afún ó ni fẹerefe

pẹle pe àni tó pe

Pegue a folha devagar, cuidadosamente devagar, cuidadosamente

A folha é um dom, uma alegria que virá

devagar, cuidadosamente

Cantiga da nação Ketu ${ }^{1}$

Este artigo é fruto de uma pesquisa sobre a trajetória de Dorival Caymmi. ${ }^{2}$ Contudo, ao invés de delinear o percurso profissional-biográfico ou apresentar uma análise interna das criações deste famoso cantor e compositor baiano, ${ }^{3}$ o presente texto pretende abordar sua figura de um ponto de vista alternativo e, talvez, inusitado. Evidentemente, a vida e a obra de um artista tão importante para a chamada música popular brasileira, ${ }^{4}$ para a criação de um imaginário regional baiano ainda vigente (Cf. Carvalho 2010), ou mesmo para a consolidação de certa identidade nacional cordial e mestiça, na primeira metade do século XX (Cf., e.g., Costa 2001; Seigel 2009), permitem as mais diversas abordagens. Neste artigo, porém, nos aproximaremos dessas e de outras questões lateralmente. Elas servirão, na verdade, como pano de fundo para algumas considerações que farei a respeito da construção social, da manutenção e da extensão da pessoa ou persona e do corpo ${ }^{5}$ de Caymmi. 
As diversas linhas argumentativas que compõem este artigo partiram de uma questão muito abrangente: teria este ícone, este produto Dorival Caymmi, amplamente vendido e veiculado por ele próprio e pelos outros, se tornado atrativo e eloquente através da ambiguidade inerente ao trânsito entre determinadas condições de inferioridade e superioridade sociais relativas (negro/mestiço, genuíno/construído, único/replicável, popular/sofisticado, baiano/carioca etc.)? É difícil responder a tal pergunta categoricamente, mas levantarei aqui alguns elementos para pensá-la.

Com este objetivo, apresento dois momentos etnográficos (Strathern1999) que, concentrando-se no "último ato individual, civil, social da [sua] vida" (Thomas, Louis-Vincent citado em Lima 2010:285), giram ao redor das ideias de presença e ausência. O primeiro, mediado por fontes on-line, relaciona-se com o enterro de Dorival. O segundo trata dos desdobramentos de uma visita que fiz ao local de seu falecimento. Como já deve ter ficado evidente, a morte deste artista levanta, ou melhor, torna visíveis várias relações materializadas em imagens, espaços e coisas. Estas presenças concretizam-se, de modo particularmente significativo numa circunstância e num par de objetos vinculados ao candomblé baiano, que são importantíssimos e que aparecerão ao longo de todo o texto. Estes objetos - um prato de comida encontrado na última residência de Caymmi e uma pedra guardada no Ilê Axé Opô Afonjá, em Salvador - relacionam-se intimamente com o cargo que ele assumiu neste mesmo terreiro e que foi herdado por outro músico conhecido: Gilberto Gil. ${ }^{6}$ Tudo isso compõe os assentamentos de Caymmi, ou seja, a criação, o fortalecimento e a manutenção de sua pessoa ritual (Cf. Sansi 2005; Goldman 2012; Dos Anjos 2008), e servirá como esteio deste texto que vai, assim, do enterro do nosso protagonista até sua última comida de santo, desta oferenda doméstica até seu posto litúrgico e deste cargo até a pedra de seu otá. ${ }^{7}$

Acontece que estes itens da parafernália sagrada dos cultos afrobrasileiros, ${ }^{8}$ esta sucessão ritual e as crenças que acompanham ambas as coisas não serão tratados somente como objetos de análise. O candomblé inspirou teórico-metodologicamente a pesquisa que realizei e a escrita deste texto. Em outras palavras, ele é tomado aqui como uma verdadeira episteme, uma vez que suas formas de conhecimento permeiam todo este trabalho. Destaco, dentre este conjunto algo rizomático e eminentemente prático de conceitos e símbolos condensados em ditados e ações (Cf. Goldman 2009; Dos Anjos 2008; também Turner 1970), as noções de catar folhas e de enredo que estruturaram a concepção deste artigo, embora não sejam diretamente abordadas nele. A expressão catar folhas refere-se ao modo de adquirir novos conhecimentos num terreiro: sem ensinamentos explícitos, formais, o aprendiz deve catar fragmentos e indícios daquilo que quer saber até poder 
montar, retrospectivamente, um entendimento ou uma imagem do novo fundamento ou habilidade obtida. Enredo, por sua vez, expressa as ligações entre coisas aparentemente díspares e que, no entanto, se cruzam no interior de um mito ou de um rito, se influenciam mutuamente e guardam uma relação de homologia. Obviamente os enredos também passam pela mesma política de transmissão do conhecimento, sendo revelados paulatinamente aos fiéis. Ambas as noções se vinculam, consequentemente, com a ideia de segredo que será apresentada e discutida no final deste artigo.

A linha mestra deste trabalho corresponde ao avesso de seu subtítulo e procura mostrar as presenças subjacentes à ausência e ao silêncio inerentes à morte e à finitude. A partir deste paradoxo inicial - espelhado na manutenção do sucesso de Caymmi apesar da velhice e do desaparecimento do seu corpo físico - o presente ensaio lança mão da ideia de ambiguidade. Conforme veremos, as narrativas que circundam a persona de Dorival são, sobretudo, ambíguas. Ao invés de lutar contra ou tentar desconstruir esse traço tão marcante na etnografia post-mortem que realizei, meu texto busca incorporá-lo duplamente: enquanto tema e estratégia narrativa. Como reza sua conclusão, há coisas que não podem ser ditas de outra maneira. Tentarei, por fim, aproximar estes elementos todos de uma discussão sobre raça e racialização, ${ }^{9}$ abordando estes temas, ainda que de forma incipiente, em uma chave inabitual.

\section{Emblemas}

Dorival Caymmi não morreu. Seu corpo físico ou biológico - velado na Câmara dos Vereadores da cidade do Rio de Janeiro entre os dias 16 e 17 de agosto de 2008 e, logo em seguida, enterrado no Cemitério de São João Batista, na Zona Sul da capital fluminense - parece ter sido, afinal, apenas um dos inúmeros suportes da persona do "cantor das graças da Bahia".. ${ }^{10}$ Até mesmo as reportagens e, especialmente, as imagens do enterro de Caymmi mostram alguns dos outros corpos que construíram, sustentaram e propagaram a imagem deste artista. As fotografias profissionais e amadoras referentes àquele domingo, facilmente acessíveis on-line, ${ }^{11}$ registram, afinal pelo menos dois aspectos da expansão dos muitos corpos de Dorival.

De um lado, a superposição de pertencimentos múltiplos do compositor baiano expressa-se de modo direto e singelo nas diversas bandeiras que durante o velório foram cobrindo seu caixão. As bandeiras do Brasil, da Bahia e do Rio de Janeiro, da escola de samba Estação Primeira de Mangueira e do Flamengo, cruzadas por faixas de várias instituições públicas e privadas, 
resumiam parte da biografia de Caymmi. Ali estavam reunidos o jovem músico nascido na "velha São Salvador"12 e o velho "patriarca da música popular" (Amado, J. 1972) que, depois de viver por umas cinco décadas o cotidiano carioca, havia sido homenageado pela Mangueira, protagonizando o enredo campeão do carnaval de 1986 ("Galeria do Samba..." s/d).

Estes emblemas encontravam-se em um contexto maior. O saguão de entrada da Câmara de Vereadores, o mausoléu da cantora Carmen Miranda, que fica a menos de 50 metros do túmulo de Dorival, e o próprio Cemitério de São João Batista - conhecido popularmente como "o cemitério das estrelas", onde estão sepultados, por exemplo, todos os imortais da Academia Brasileira de Letras, diversos presidentes do Brasil, ministros do Império e personalidades diversas, tais como Heitor Villa-Lobos, José Pancetti e Antônio Carlos Jobim ("Cemitério de São João..." s/d) - compunham o cenário daquelas cerimônias fúnebres. Este entorno formava, evidentemente, um palco superpovoado, cheio de relações presentes e de enredos passados, com o qual as flâmulas sobrepostas estabeleciam uma espécie de diálogo tácito.

Tanto a figura delineada pelo poliéster das bandeiras e das faixas quanto esse pano de fundo expressivo indicavam o enorme reconhecimento que Dorival havia obtido em sua longa trajetória artística e biográfica. De certa forma, aquela era apenas mais uma das incontáveis homenagens públicas, dos verdadeiros rituais de entronização e de assentamento coletivo que ajudaram a moldar a figura desse "Buda nagô" (Moreira 1991, lado A, faixa 4), repartindo - entre seus colegas, intelectuais, familiares e políticos - "as pratas e os ouros"13 simbólicos acumulados por ele.

Essas relíquias, inscrições e tributos tratava-se, portanto, de materializações e extensões do corpo de Dorival. Por certo, eles não foram produzidos per se, como meros epifenômenos de determinadas relações sociais, mas também não poderiam ter retirado a sua eficácia imensa - embora relativa, uma vez que o bronze dos monumentos e as manchetes antigas estão fadados à ressignificação constante e, no limite, ao esquecimento do seu referente original - somente do "vento que faz cantigas nas folhas do alto do coqueiral". ${ }^{14}$ 


\section{O corpo do patriarca}

Foi Dorival Caymmi quem nos deu

a noção da canção como liceu.

A cada cem anos

um verdadeiro mestre aparece entre nós

e entre nós alguns que o seguirão,

ampliando-lhe a voz e o violão.

\section{Gilberto Gi1 ${ }^{15}$}

O segundo aspecto da multiplicação dos corpos de Dorival, patente nas fotografias de seu enterro, é a presença de muitas outras personalidades públicas, ao lado de familiares pouco conhecidos, vizinhos etc. Cada uma destas pessoas ilustres e anônimas foi, afinal, corresponsável pela expansão da figura de Caymmi e pela manutenção do êxito do longevo compositor. Foram elas que, em parceria com o próprio artista, souberam propor, sustentar e orientar o sentido de todas as honrarias descritas acima.

As imagens da internet mostram-nos, por exemplo, Gilberto Gil consolando a sua ex-mulher, Nana Caymmi, filha mais velha de Dorival. Gil é, aliás, um dos obás de Xangô ${ }^{16}$ do terreiro do Axé Opô Afonjá. ${ }^{17}$ Ele é o atual Obá Onikoyi desta casa de santo. Este cargo, equivalente à pessoa litúrgica de seu possuidor, é normalmente transferível post mortem. Acontece que Caymmi pertenceu à comunidade do Opô Afonjá, sendo, precisamente, o antigo Obá Onikoyi da casa. Neste caso, Gil - o herdeiro desta parcela importante da persona de Dorival - congregava, refletia e agia sobre diversas partes articuladas do corpo de seu velho mestre, do nome sagrado à memória profissional, da descendência consanguínea à matéria inerte.

Além do criador de "Buda Nagô", músicos das mais diversas idades e tendências aparecem nas fotografias. Em outro site, os dois filhos mais moços do "enternecido poeta dos pescadores" (Caymmi, D. \& Amado, J. c. 1967:9), Dori e Danilo, podem ser vistos segurando o caixão do pai à frente de uma pequena multidão. Diversos atores e teledramaturgos ligados à Rede Globo de Televisão, ${ }^{18}$ João Ubaldo Ribeiro, a neta e biógrafa Stella, o então secretário de Cultura do estado da Bahia, Márcio Meirelles, e o prefeito do Rio, César Maia, dentre muitos outros, tocam o caixão do falecido, choram, abraçam-se e conversam durante todo o enterro.

Por intermédio de figuras como essas, Dorival Caymmi conseguiu propagar e intensificar as suas atividades pessoais, sobretudo, artísticas, durante a sua longa velhice, a ponto de converter-se numa verdadeira 
entidade, num santo ou numa instituição consagradora - mesmo tendo se afastado progressivamente dos palcos, estúdios e espaços públicos durante essa fase da vida...

O mass media principal, aquele que asseguraria de fato a expansão dos corpos de Caymmi, foi a indústria fonográfica brasileira, associada, é claro, a todos os outros ramos do show business - incluindo a televisão.

O sucesso do cantor e principalmente do compositor Dorival Caymmi nas décadas de 1930 a 1950 permitiu que suas canções fossem interpretadas logo por outros artistas. Assim, desde os primeiros anos de sua duradoura carreira, ele veria a sua obra propagada por diversos outros músicos. Evidentemente, no caso dos compositores de música popular, isto não é nada excepcional. Muito mais relevante do que o número considerável dessas primeiras regravações é a transformação precoce de Dorival numa espécie de patriarca e de antepassado que se deu ainda nos anos 50. A partir do lançamento do primeiro álbum de João Gilberto - o LP Chega de Saudade, de 1959 (Oliveira 1959), que talvez seja o disco mais influente da MPB e que teria contado ainda com o incentivo paternal de Caymmi antes mesmo de sua gravação, nos corredores da Odeon - o "gênio da raça"19 converterse-ia numa autoridade musical incontestável, numa entidade que poderia emprestar sua força, seu axé, para os jovens talentos das novas gerações. Dorival, aos 45 anos de idade, já podia ver, portanto, os primeiros sinais do seu interminável processo de envelhecimento social.

As gerações de cantores e de compositores que se formaram por conta de "uma admiração pela Bossa Nova" (Caymmi, D. 1985, disco 1, faixa 8) trataram de seguir, desde então, o exemplo de João Gilberto, o "mestre imediato" de todos eles. Ainda que tivessem propostas musicais contrastantes e participassem de movimentos artísticos diferentes, os jovens tropicalistas baianos - como Gal Costa e Gilberto Gil - de um lado, e os próprios filhos de Dorival - Nana, Dori e Danilo Caymmi, sempre acompanhados pelo veterano Tom Jobim - de outro, vincularam-se conscientemente à linhagem estética, à "casa real" (Moreira 1991, lado A, faixa 4) encabeçada pelo venerável compositor. De acordo com Caetano, João dizia: "a gente deve estar sempre aprendendo com Caymmi. Aprenda tudo com ele" (Caymmi, D. 1985, disco 1, faixa 8).

Esses intérpretes, enfim, duplicariam a imagem musical de Dorival Caymmi na segunda metade do século XX, desdobrando as duas tendências que estavam reunidas, de modo latente, na reapropriação do compositor feita por João Gilberto a partir de 1959. A família Caymmi, por exemplo, insistiria numa versão sofisticada, jazzística e jobiniana do "patriarca da música 
popular". Os tropicalistas, a Rede Globo e o próprio Dorival ${ }^{20}$ apostariam na identificação atávica das canções do "enternecido poeta dos pescadores" com o povo e a paisagem da velha Bahia.

Todos esses regravadores mais jovens da obra de Caymmi desenvolveriam, no final das contas, algo como "uma paixão total" (Caymmi, D. 1985, disco 1, faixa 8) pelo patriarca de suas diversas linhagens. Dorival tornou-se "uma coisa, assim, de uma beleza ilimitada", dotado ainda de "uma sabedoria muito profunda, né?, que ele parece ter tido desde sempre" (Caymmi, D. 1985, disco 1, faixa 8). Esse progressivo endeusamento do compositor chegou a ponto de ele acabar seguindo o destino dos antigos reis divinizados dos iorubás, os orixás do candomblé: seus filhos e discípulos passaram a incorporá-lo, reduplicando seu corpo, sua pessoa e sua imagem nos discos ou nos palcos.

\section{Intimidade}

\section{Intermezzo}

Dentre as inúmeras fotografias do velório de Dorival, uma das mais tocantes - pelo menos para mim - nos mostra um menino desconhecido. Ele deve ter uns 10 anos de idade e talvez seja um dos Caymmi mais jovens, um dos bisnetos do compositor. De todo modo, Nana apoia a mão em suas costas enquanto ele beija, de olhos fechados, a testa do velho patriarca, com um respeito evidente.

Essa imagem traz consigo - ainda que o nome e o parentesco da criança fotografada sejam ignorados - uma espécie de olho mágico que nos deixa entrever, através de um ângulo estreito e com um grande coeficiente de distorção, uma parcela da vida privada do "cantor e intérprete do seu povo" (Amado, J. 1972). A vida íntima do ilustre compositor, que se revelou muito pouco acessível ao longo da pesquisa que realizei, parece ter sido rodeada e protegida por um silêncio, no mínimo, compreensível.

Afora alguns recortes de jornal, eu só pude vislumbrar a privacidade do velho artista na arrumação permanente da sua última residência, nuns poucos manuscritos encontrados ao longo da pesquisa e, finalmente, nas lembranças afetuosas de seus parentes e amigos. 


\section{Ói eu! ${ }^{21}$}

Foi depois de uma longa entrevista com Dori Caymmi que eu ouvi, pela primeira vez, o seguinte: "Pronto, agora dá pra você fazer mestrado, doutorado, congado e reisado!".

A frase era ambígua. Nela, e no sorriso sem graça que a acompanhou, havia a um só tempo um jogo humorístico de palavras, um desafio implícito, a constatação de que ele, Dori, tinha falado demais e, principalmente, ironia.

Dori havia marcado a entrevista comigo às 14 horas do dia 03/05/2012 num sexto andar da Rua Ronald de Carvalho, em Copacabana. Eu sabia que aquele tinha sido o último apartamento da vida de seu pai. Uma placa de bronze, que ficava logo na entrada do prédio, trazia as linhas que transcrevo abaixo:

DORIVAL CAYMMI NASCEU EM SALVADOR BA EM 30/04/1914. Neste prédio - junto ao mar que tanto exaltou - viveu seus últimos dias onde faleceu em 16 de agosto de 2008 .

Cantor e compositor de notável talento, o conjunto de sua obra engrandece a música brasileira.

EDIFÍCIO ADRIANO DE BARROS

Essa homenagem ao ex-morador ilustre conseguiu aumentar minha expectativa, que já era grande. Uma parcela importante do meu tema de pesquisa estaria certamente materializada ali. Eu procurava, afinal, uma justificativa e uma metodologia suficientemente boas para estudar a trajetória daquele "notável talento".

O pai de Dori, tendo vivido "seus últimos dias" naquele prédio e sendo um indivíduo envelhecido que pouco saía de casa, deve ter visto da sua janela os bares, a feira semanal e o mesmo pedaço da praia de Copacabana que eu também podia ver no início daquela tarde. No seu apartamento, além da própria disposição dos cômodos, talvez ainda restassem alguns de seus pertences pessoais e instrumentos de trabalho, como o seu violão. Por outro lado, outros interesses meus - as homenagens e o conjunto de temáticas que estavam relacionados indissociavelmente com a figura pública de Dorival Caymmi - também estavam ali, e de modo ainda mais concreto, ao alcance da minha mão. Naquela placa de bronze, afinal, cabiam em poucos centímetros o mar de suas Canções Praieiras, a Bahia de sua juventude, o Rio de Janeiro, onde o artista passou a maior parte da vida, e o seu talento incomum que teria influenciado e enobrecido a "música brasileira" como um todo. 
Eu estava intimidado. Conseguir prestar atenção a toda aquela série de elementos, objetos e discursos intercruzados e sedimentados não seria fácil. Descobrir significados ocultos, ligações e intencionalidade em tudo, adotando uma espécie de método crítico-paranoico à la Salvador Dalí (Dalí 1974), também não seria uma boa ideia. Preocupar-me exclusivamente com os aspectos técnico-metodológicos da entrevista de Dori até poderia ter sido interessante. Porém, desse jeito, eu deixaria passar uma oportunidade que talvez fosse única. Estar num local, enfim, bastante significativo para a vida pessoal de Caymmi, num cenário em certa medida importante para a construção coletiva de suas mitologias, ${ }^{22}$ máscaras e personas, e deixar de percebê-lo etnograficamente, de pensar a respeito das interações simbólicas materializadas ali parecia ser um contrassenso.

Toquei o interfone pontualmente e fui recebido por Dori com impaciência. Ele foi logo dizendo que estava com dor no pé e tinha que botar gelo no machucado, que precisava almoçar e que uma repórter iria aparecer em algum momento para fazer uma matéria. Helena Leal, sua esposa e produtora, estava por perto, mas não falou mais do que "boa tarde" inicialmente. Ela parecia querer observar-me discretamente e às vezes ia até a cozinha onde o almoço estava sendo preparado por alguém que não cheguei a ver. Nas paredes da sala estavam mais ou menos uns 15 quadros de Dorival, que também havia sido um pintor amador habilidoso. A princípio tive que me controlar para não ficar encarando as telas, mas percebi que os mais antigos estavam datados dos anos 1940. Bem na minha frente, atrás de Dori, estava a pintura de uma sereia mergulhada n'água e nos oxés ${ }^{23}$ de Xangô que servira de base para a capa do LP Caymmi, de 1972.

Em outros cantos estavam dois autorretratos, num deles, em diversos tons de marrom, um jovem Dorival olhava-nos severamente. Havia também uma tela incompleta perto de uma cadeira de balanço, da coleção de bengalas que a sua neta Stella havia fotografado para a sua biografia (Caymmi, S. 2001:554) e de uma janela que dava para o mar. A foto deve ter sido tirada em outra casa. De acordo com a primeira fala de Dori, afinal, seus pais viveram naquele prédio apenas entre dezembro de 2007 e agosto de 2008.

As bengalas arrumadas num cesto de vime e todos os outros objetos do "universo pessoal" (Caymmi, S. 2001:554) caymmiano que apareciam fotografados no livro haviam sido dispostos de maneira muito semelhante, contudo. O apartamento todo, aliás, dava uma impressão incômoda. Muito mais do que a materialização de uma experiência já passada, que eu esperava encontrar quando estava lá embaixo, parecia que Dorival estava vivo e que poderia aparecer a qualquer momento. As coisas não deviam ter mudado de lugar naquele apartamento desde sua morte. Essa possível dificuldade 
de lidar com o desaparecimento da pessoa e de algumas das personas de Caymmi talvez explicasse alguns detalhes inusitados daquele espaço. Num de seus cômodos, por exemplo, em cima de um armário, havia um prato de barro cheio de comida ressecada. Era uma oferenda pessoal ${ }^{24}$ de um seguidor do candomblé que havia sido feita quando Caymmi vivia e que ainda não tinha sido retirada.

Fazê-lo não é algo simples para quem acredita nos orixás (Cf. Santos 1976). Não é à toa que outro dos filhos de Dorival, Danilo Caymmi - numa entrevista, realizada no dia 23/05/2012 - contou-me depois, com muita hesitação, a seguinte história:

Dentro daquele apartamento você viu um altar de Xangô, os assentamentos dele estavam lá. Mamãe, antes de morrer, mandou o Guto, que é meu produtor aqui, [levar] os assentamentos dela de volta pro candomblé do Gantois. O candomblé de Mãe Menininha, porque mamãe era filha de lá, desse candomblé. E papai era do outro, do Axé Opô Afonjá, [de] onde toda a minha família vem, desde o meu avô. Frequentavam o meu avô Durval, meu pai. Eu também sou [do Opô Afonjá], tenho assentamentos no [terreiro]... o meu assentamento tá no Axé [Opô Afonjá]. Mas eu não sabia o que aconteceu. Esses assentamentos [isto é, os assentamentos de seu pai, Dorival Caymmi] tavam lá [no apartamento]. Ele faleceu, [...] eu via umas coisas só, no alto [do armário]. Aí uma sobrinha minha tirou aquilo e aconteceu uma coisa incrível, que chamou a atenção. O Dori tava sentado com o apartamento fechado. Foi no apartamento, tava tudo com a janela fechada, pulou um vaso e ZUM no chão PÁ! Eu falei: "Bom, nisso aí tem coisa". Caiu do nada e a gente foi ver, pedir a uma outra [mãe de santo], uma mãe de santo [d]o Rio de Janeiro que entende mais de candomblé. Ela falou: "Pô, os assentamentos dele tão aqui. Eu não vou [tirar]... como é que vai fazer?"25

A própria utilização da casa, que também se reflete na história, aliás, era curiosa. O apartamento fica fechado a maior parte do tempo e quando Dori, que vive no exterior, vem ao Rio de Janeiro, ele ocupa o espaço por uns dias. Era este o caso quando o entrevistei.

Ao longo de nossa conversa, contudo, a impaciência inicial e essa configuração de relações entre sujeitos e objetos foram mudando uma a uma. Logo no início, por exemplo, o filho de Dorival me aproximou espontaneamente de um dos quadros pintados por seu pai, dizendo: " $\mathrm{E}$ você olha pra cara dela na fotografia, vê se dá pra convencer ela de alguma coisa...". Aquilo que Dori chamava de "fotografia" era, na verdade, um admirável retrato a óleo de sua mãe, Stella Tostes Caymmi. Depois nos sentamos para almoçar, Helena, a esposa, passou a participar bastante da entrevista e os compromissos de Dori foram adiados até as 6 horas da tarde, 
quando ele finalmente disse, referindo-se à repórter: "Mas é isso, eu vou tomar um banho que daqui a pouco vem uma mulher aí que tenho que cantar não sei o quê...", e eu desliguei o gravador, encerrando o seu depoimento.

Terminada a gravação, Dori quis me mostrar a casa junto com Helena, cômodo por cômodo. Foi aí que vi o tal "altar de Xangô" e a cama em que Dorival havia falecido. Dori deu um tapinha num dos travesseiros e disse: "papai morreu aqui". A sensação incômoda da presença de Caymmi era cada vez maior para mim, exatamente por estar vendo ali uma imagem incontestável e contraditória de sua ausência. Talvez o sentimento fosse compartilhado pelo casal, embora Dori já houvesse falado que não ficava muito impressionado com essas coisas e que conviveria bem, de certa forma, com o pai morto, ainda que ele fosse um fantasma. O filho de Dorival havia comentado que ele era silencioso dentro de casa, chegando a dizer, inclusive, que ele fora um pai ausente até certo ponto. Em outro trecho da sua entrevista Dori, emocionado, mudou de opinião:

E eu não tenho nem constrangimento, eu durmo no quarto, durmo na cama que ele morreu. Eu não... pra mim isso não... eu não acredito em fantasma não. E se ele fosse fantasma, seria um fantasma ótimo, eu bateria altos papos com ele. A noite inteira ficaria acordado, só conversando. Mas ele era um ótimo papo e as pessoas adoravam isso nele.

Talvez o fato de que nossa entrevista tivesse durado uma tarde inteira, contrariando a expectativa inicial de Dori, fosse responsável pela frase do "congado e reisado" que seria repetida por Danilo vinte dias depois. ${ }^{26}$ Talvez a exibição tão explícita de suas emoções o deixasse constrangido na frente de um estranho. De qualquer forma, havia uma boa dose de ironia ali, disfarçando todas essas coisas e lançando uma espécie de desafio para mim. A sensação que eu tive ao sair daquele apartamento e ao abrir a porta do elevador me trouxe, subitamente, uma lembrança da minha experiência de campo anterior.

Os jongueiros do interior do estado de São Paulo por mim estudados num mestrado em História Social (Queiroz 2011) não eram artistas conhecidos fora de suas localidades, mas também começaram seus depoimentos desconfiados. Os mestres e os curandeiros também falavam muito, ao final das contas, utilizando as palavras com uma maestria impressionante, dando, aliás, mais informações do que eu poderia utilizar. Por fim, eles também se despediram de mim de um jeito meio estranho e irônico. Seus olhos pareciam dizer "sim, mas o que é que você é capaz de fazer com tudo isso?". 


\section{A matéria-prima dos sonhos}

Stella, filha de Nana Caymmi, é neta e biógrafa de Dorival, tendo publicado ainda dois trabalhos acadêmicos sobre o tema (Caymmi, S. 2001, 2008, 2013). Ela escreveu num dos capítulos finais do seu primeiro livro sobre o avô, na época ainda vivo, que ele "gosta de se aproximar da janela a qualquer hora do dia - critica muito quem encosta móvel interditando o livre acesso a ela" (Caymmi, S. 2001:553). A observação insólita seria confirmada por diversos ex-vizinhos do artista que fui encontrando enquanto fazia viagens de pesquisa no Rio de Janeiro e em Salvador.

A janela aberta à curiosidade da vizinhança, o violão de Caymmi - duas vezes roubado e restituído de acordo com as suas duas biografias (Barbosa \& Alencar 1985; Caymmi, S. 2001) - e a placa de bronze do Edifício Adriano de Barros são elementos mais tangíveis do que o processo de envelhecimento ou as outras características que desempenharam o papel de verdadeiros temas transversais nas entrevistas que realizei com artistas, intelectuais, amigos e familiares de Caymmi. Estes temas, que passo a chamar assim a partir de agora, aparecem, afinal, em todas elas e são aparentemente muito significativos. E ainda que essas coisas - janelas, instrumentos, bronzes e vasos que pulam sozinhos - se trate de entes concretos, de objetos que têm uma circulação um pouco mais restrita, eles também tiveram (e ainda têm) uma enorme importância para a construção da pessoa do compositor. Esses itens também foram/são capazes de condensar materialmente, enquanto elementos icônicos ${ }_{1}{ }^{27}$ determinadas relações e percepções coletivas sobre o indivíduo e/ou a pessoa de Dorival. É possível que a própria tangibilidade desses objetos os converta em elementos semânticos sui generis, singularmente capazes de agregar significados às experiências pessoais $d o$ e em relação com o artista.

A velhice de Dorival Caymmi - de que eu me apropriei para pensá-lo naquela tarde passada com Dori - parecia, por outro lado, ter um outro peso, uma concretude diferente. Boa parte de sua eficácia peculiar parecia residir em seu caráter parcialmente intangível. O envelhecimento daquele músico famoso não estava ali na minha frente, ao alcance da mão, parecendo, inclsuive, ser feito da "matéria-prima dos sonhos" - parafraseando uma bela expressão de Freud (2001).

É claro que a velhice de Caymmi não pertencia exclusivamente à minha imaginação, mas, por outro lado, ela não poderia ser resumida a uma série de circunstâncias e processos biológicos. Na verdade, tratava-se de uma imagem icônica, plurissignificativa e associada recorrentemente à figura do artista. As marcas físicas de sua longevidade formam, enfim, um 
dos estereótipos que se repetiriam de uma maneira ou de outra em todas as fontes de pesquisa disponíveis sobre Dorival: os meus temas transversais. Eles podem ser considerados verdadeiros precipitados discursivos, Em outras palavras, estes temas contituem-se de metonímias e de outras tantas imagens verbais que aparecem reiteradamente nos discursos que têm como referente o "cantor e intérprete do seu povo". Tais precipitados se sobrepõem e sintetizam, ademais, um conjunto de ideias, projeções e narrativas vinculadas coletivamente à persona do compositor, tratando-se, portanto, de símbolos poderosos capazes de influenciar nossa experiência (cf. Turner 1970), nossa imaginação e nossa relação com ela. Foi por meio destes signos repetitivos que eu pude entrever aos poucos uma espécie de mitologia caymmiana.

A trajetória e a história pessoal do indivíduo Caymmi - um jovem baiano simpático nascido em 30/04/1914 de "Côr parda, Cabelo crespo, Olhos cast. escuros, Altura 1m.66, Nariz grande, Rosto oval [e] Boca regular", "cart. de Ident. $n^{\circ} 118022$ ", que deixou a sua terra natal em 01/04/1938 e logo fez sucesso no Rio de Janeiro, tornando-se um músico internacionalmente famoso nas décadas seguintes, casou-se em 30/04/1940, teve muitos amigos e três filhos, envelheceu, conseguiu ampliar cada vez mais o seu prestígio no panteão da música popular brasileira e morreu em 16/10/2008 ${ }^{28}$ - são imediatamente refratadas em múltiplas perspectivas através desses núcleos semântico-temáticos.

Os dados documentais, os fatos recém-listados e a materialidade dos objetos mencionados nos parágrafos anteriores parecem tornar-se paradoxalmente menos reais do que as próprias inter-relações formadas por aquilo que chamei de temas transversais e pelas imagens que surgem através dos cruzamentos de todas essas fontes de informação. Tais relações, reitero, são muitas vezes intangíveis - mas nem por isso menos reais - e acabam formando uma trama de fino bordado que é tecida continuamente, toda vez que alguém descreve a pessoa de Caymmi recorrendo a este mesmo repertório de clichês e estereótipos. Este discurso compartilhado talvez seja a própria "matéria-prima dos sonhos", afinal. De todo modo, é ele que conecta as personas criadas pelo músico, aquelas que foram criadas a partir dele, e os personagens de suas canções.

A mitologia caymmiana pode, enfim, nos aproximar, se levarmos em conta as inúmeras mediações, os exageros e os espelhamentos da biografia e das artes do "gênio da raça". Por outro lado, esses mesmos conteúdos impossibilitam qualquer leitura essencialista, unitária e ingenuamente coerente do meu sujeito de pesquisa (cf. Bourdieu 1986). Caymmi pode ser subdividido em uma série de objetos analíticos diferentes que dialogam entre si e que têm como pano de fundo certos temas muito mais amplos, 
como as relações raciais no Brasil. Nos próximos itens deste artigo reproduzo grosso modo o percurso que me levou dos temas transversais particulares encontrados, pela primeira vez, nas entrevistas que fiz no início da minha pesquisa - a essas macropreocupações.

\section{Cabelos brancos, aquela coisa toda}

Dori fez um show na Unicamp no dia 29/03/2012. Naquela ocasião, poucos dias antes do aniversário de seu pai - Caymmi faria 98 anos se estivesse vivo - ele cantou e tocou o repertório de seu último disco, dedicado às suas composições mais recentes (Caymmi, D. T. 2011). A capa do álbum traz uma fotografia do artista com uns 4 ou 5 anos de idade abraçado com o icônico violão de Dorival. Durante o espetáculo Dori - depois de cantar emocionado a música "Velho do Mar", que no disco tem seu título complementado por um "meu pai" entre parênteses - empregou várias vezes a expressões velho e meu velho para referir-se a ele, numa fala dirigida à plateia.

A velhice e a progressiva falência do corpo físico de Dorival Caymmi formam, como vimos anteriormente, um dos pontos fulcrais na construção da imagem, da pessoa de Caymmi, junto com a raça, a genialidade, a sexualidade, a autenticidade, a religiosidade, a preguiça e a sabedoria. Estes temas são muitas vezes sobrepostos e podem se aglutinar de muitas maneiras a depender de quando, onde e quem fala. A maioria deles é empregada em situações que envolvem uma boa carga de dubiedade. Essa ambivalência é tão intrínseca e definidora que, acredito, pode ser tratada como um elemento estrutural. Os temas transversais desempenham, em resumo, o papel de símbolos polivalentes, de significantes que podem atrair um número incomum de significados.

Através da comparação entre as entrevistas que realizei, a bibliografia específica e diversas fontes primárias, dediquei-me basicamente a fazer duas perguntas muito simples de formular e difíceis de responder. Por que estes e não outros temas transversais aparecem associados especificamente a Caymmi e como esses temas puderam virar lugares-comuns ou verdadeiros estereótipos permeando, sem combinação prévia, a fala, a escrita ou o olhar de tanta gente diferente durante pelo menos quarenta anos?

A polivalência de uma dessas imagens prototípicas - a da velhice como signo autossuficiente e, simultaneamente, como pretexto para expressar outros assuntos - marcou, por exemplo, o início da entrevista que realizei com Gilberto Gil, em 11/04/2012. Nela, a velhice de Caymmi era ao mesmo 
tempo um elemento descritivo e um link para expressar o pertencimento de Gil a uma espécie de linhagem de discípulos, descrever uma cerimônia que demonstrava o respeito que "amigos, colegas" dedicavam ao idoso artista quando ainda estava vivo, e indicar principalmente o afeto que ele sentia por Dorival.

É, claro, embora eu tenha lembranças também, eu me lembro qual foi a última vez que eu estive com ele, foi quando ele fez 90 anos. Ele morreu aos 94, né? Quando ele fez 90, todos os discípulos, amigos, colegas deles foram cumprimentá-lo numa reunião que se fez pra comemorar o aniversário dele, aqui, no antigo Palácio do Rio de Janeiro. E eu me lembro dele já na cadeira, já sem nem poder propriamente levantar e circular pela festa. Ficou ali recebendo as pessoas e eu fui falar com ele, ele levantou os olhinhos assim e "uh, Gil!". E eu dei um beijo nele, e lhe afaguei o cabelo, o algodão. Como costumam falar, o algodão. Ele tinha até esse apelido, né, o Algodão, por causa do cabelo, fartos cabelos brancos macios e cabelos brancos, aquela coisa toda.

Por outro lado, nas entrevistas feitas com os parentes do compositor, a interação muito grande com esse indivíduo, Dorival Caymmi, parecia atribuir à sua velhice física uma série de lembranças intensas, com forte carga emotiva e, às vezes, incontroláveis. Dori e Danilo, por exemplo, descreveram com tristeza a lenta morte do pai, marcada, antes de seu falecimento, pela surdez e também pela cegueira e pelo tremor nas mãos e na voz que o teriam impedido de continuar tocando seu violão e cantando suas músicas. É importante assinalar, entretanto, que assim como havia um potencial de signo nas metonímias de Gil, nessa velhice muito mais referencial e biológica dos Caymmi há espaço, ainda que residual, para a imagem icônica e para o sonho.

Esse tema da velhice poderia conduzir o resto deste texto para uma discussão hermenêutica sobre cada um dos estereótipos caymmianos. Contudo, ao invés de seguir essa trilha - e de perder de vista os objetivos deste artigo - tentarei restringir meu foco analítico nos próximos itens. Para tanto, apresentarei os conceitos-chave de experiência racial e de silêncio. 


\title{
Silêncio
}

Intermezzo

\author{
Sensações \\ Movimento de um ser \\ Que produz \\ O seu som que produz \\ Movimento \\ E olha o vento: \\ Nele estão os sons \\ Leandro Morais ${ }^{29}$
}

Em 1949, o escritor e filósofo francês Albert Camus confessava-se, junto à nata da intelectualidade brasileira, "totalmente seduzido" pelo talento de Dorival - "um negro que compõe e escreve todos os sambas que o país canta", de acordo com seu diário de viagens (Camus 1997:99). Poucos anos depois, em 1953, a Câmara Municipal de Salvador fez a primeira homenagem pública de grande porte para o compositor, nomeando a praça principal de Itapuã com seu nome (cf. Barbosa \& Alencar 1985; Caymmi, S. 2001). Aparentemente, a persona de Caymmi já estava em adiantado processo de construção naquele momento.

Entre esses dois eventos - um deles ocorrido no âmbito privado e o outro fartamente divulgado pela imprensa - os críticos especializados e principalmente o público consumidor haviam conduzido Dorival ao auge da fama. Resumindo, o músico já era um ícone da música popular brasileira antes de completar 40 anos de idade e curiosamente, sua imagem já estava bem assentada e estereotipada de acordo com os signos metonímicos ou os temas transversais elencados neste artigo. A partir de então, o indivíduo Dorival veria a sua figura pública ser retrabalhada ad infinitum por ele e por outros artistas. O compositor - conforme indicado no início deste texto - foi sendo substituído pelo próprio imaginário criado por ele e através dele, uma vez que seu corpo físico, cada vez mais envelhecido, se afastara dos palcos e dos estúdios.

Seria possível, porém, mudar o andamento do presente artigo, modular sua tonalidade principal e, indo um pouco mais longe, tentar relacionar os dados biográficos apresentados até aqui e, especialmente, a construção dos corpos múltiplos de Dorival Caymmi com os temas da raça e da experiência racial do artista? 
Pressupondo o caráter não natural/essencial das "raças" humanas, assim como o aspecto íntimo/cotidiano dos jogos classificatórios que fazem a "raça" coexistir, de forma relacional, com as memórias sentimentais, estéticas, religiosas e corporais dos sujeitos e dos coletivos, podemos, afinal, perguntar - por certo em caráter exploratório e preliminar - se e por que o corpo de Caymmi era um corpo racializado, isto é, marcado por uma cor ou um fenótipo socialmente significativo e controverso.

O tópico da raça foi indiscutivelmente uma das imagens prototípicas mais recorrentes da pesquisa que fiz e da mitologia caymmiana que deduzi a partir dela. Com o passar do tempo, esta questão acabou se mostrando cada vez mais pertinente para a compreensão da biografia e do trabalho deste compositor. O conceito de raça poderia, ao que tudo indica, ser disposto como um espelho em relação à trajetória de Dorival, não sendo possível apreender esta última sem passar pela mediação e a reflexividade do primeiro. Em outras palavras, Caymmi e suas experiências raciais multifacetadas - que sobrepuseram, ao longo dos anos, vários aspectos particulares, familiares, simbólicos e sócio-históricos - parecem ter estado sempre conjugados indissoluvelmente, alternando-se ora como a figura, ora como o fundo de uma mesma imagem.

Neste ensaio, entretanto, a temática racial passa inevitavelmente por um desvio analítico. A atuação peculiar de Dorival Caymmi desafiava, afinal, as conceituações usuais de raça no Brasil. Os inúmeros estudos que foram produzidos sobre nossas particularidades e tensões raciais costumam situar-se ao longo de um contínuo que tem, grosso modo, duas orientações de pesquisa como extremos. Contudo, os intelectuais de ambas as vertentes - os que tenderam a buscar sobrevivências africanas, adaptações ou substratos biológico-culturais negros (e.g., Raimundo Nina Rodrigues, Manuel Querino, Pierre Verger e Melville Herskovits) e aqueles que enfatizam a mestiçagem, a convivência ou a fluidez classificatória do povo brasileiro (e.g., Sílvio Romero, Gilberto Freyre, Jorge Amado e Peter Fry) - mantiveram, de forma surpreendente, uma característica em comum. A raça adquire, ao longo de seus trabalhos, normalmente, um aspecto concreto e exteriorizado nos seus diversos traços diacríticos, contribuições, temperamentos ou fronteiras étnicas.

Caymmi foi, porém, um artista extremamente silencioso, tanto em sua vida particular quanto em sua vida pública, raramente expressando suas opiniões de forma explícita e nunca se envolvendo em disputas profissionais ou polêmicas de imprensa. Talvez ele refletisse, em sua atuação cotidiana, a vivência de seu pai, Durval Caymmi - um homem de côr dividido entre as rodas semiclandestinas de samba ou de candomblé e o universo tido 
como respeitável do funcionalismo público na Bahia da virada do século XIX para o XX - ou de seus companheiros de geração como, por exemplo, Édison Carneiro (cf. Queiroz 2019; Rossi 2016). Tanto um quanto os outros costumavam usar a burla da elegância e das boas maneiras (cf. Pontes 2010), a aquisição de bens materiais, as redes de proteção ou apadrinhamento social e, sobretudo, a discrição para contornar uma série de constrangimentos raciais e socioeconômicos.

De todo modo, Dorival jamais lançou mão de uma identidade racial definida e isenta de ambiguidades. Suas obras, por outro lado, seguiram coerentemente um padrão de negociações e soluções de compromisso entre elementos tidos como negro-baianos e uma linguagem musical peculiar, cheia de reminiscências eruditas e do jazz estadunidense. Com o passar do tempo, suas músicas foram ficando cada vez mais espaçadas e sucintas, tendendo a um mínimo expressivo e aproximando-se de uma paradoxal "expressão silenciosa" (cf. Queiroz 2019). Em outras palavras, a produção de Caymmi atingiu, nas últimas décadas de sua longa carreira, uma estética minimalista, extremamente concentrada, uma vez que suas composições - que também foram diminuindo em número - passaram a ser feitas com pouquíssimas palavras e gestos musicais elementares, expressando-se, portanto, mais pelo silêncio, pelo vazio e pela sugestão do que pelo acúmulo de informações.

O que chamo de experiência racial neste artigo, por conseguinte, é um conceito etnográfico desenvolvido a partir desta característica biográficoprofissional de Caymmi e, vale dizer, da minha relação específica com o meu sujeito de pesquisa. Esta noção, em vista disso, é indissociável do conceito correlato de silêncio, que será discutido e situado melhor nas próximas páginas. Tal perspectiva, formada pelo cruzamento dessas duas ideias complementares, trata-se, então, de uma estratégia de análise que empreguei para tentar aproximar-me das manifestações mais ambíguas das ditas "relações raciais" ou das experiências raciais multifacetadas às quais tive acesso ao longo da minha pesquisa, ou melhor, trata-se de uma tentativa de vê-las pelas canções e pelos olhos das diversas personas e indivíduos que compuseram, e ainda compõem, a figura de Caymmi. Fazendo-o, o silêncio cotidiano, racial e composicional deste músico acaba tornando-se não apenas um objeto de interesse dentre tantos outros, mas também uma importante ferramenta analítica.

É importante reiterar, por fim, que as experiências raciais discutidas aqui se dão mais pela vivência, pela admiração estética, pela reserva e pelo acesso a determinados sistemas místico-simbólicos do que por afirmações diretas, racionais e inequivocamente políticas. Além disso, as identidades, 
a experiência e em especial as categorias raciais historicamente variáveis que foram (e ainda são) empregadas para nomear, destacar ou descrever os negromestiços por vezes se expressam com muita afetividade. Em cada uma das fontes documentais consultadas - inclusive em diversos textos teóricos de intelectuais em atividade no Brasil - e em todo o meu trabalho de campo, elas acabaram atuando mais como marcadores sociais da intimidade do que da diferença. Então, em vez de forçar uma dicotomia que na verdade não existe, a conceituação silenciosa das ideias de raça e de experiência racial que proponho aqui pretende apenas lançar luz sobre um aspecto íntimo e pouco articulado de todos esses fenômenos.

No restante deste texto continuarei a falar da minha experiência de campo - revisitando, desta vez, o famoso candomblé do Opô Afonjá, que até pouco tempo tinha entre os seus membros o compositor Dorival Caymmi - e tentando avançar um pouco nesta leitura a contrapelo deste tema da raça.

\section{Auô}

O antropólogo Peter Fry parece ter acessado uma série de "lembranças muito fortes" ao falar deste tema numa entrevista que fizemos no dia 01/05/2013. Ele enfatizou, naquela ocasião, as alianças, as negociações e o convívio entre determinados indivíduos e grupos sociorraciais, mesmo encarando o conflito e a suspeita como elementos constituintes das relações interétnicas no Brasil.

Ao comentar a relação entre intelectuais, artistas e o candomblé de nação Ketu, ${ }^{30}$ de um modo geral, e mais especificamente a instituição dos obás de Xangô no terreiro do Opô Afonjá, meu interlocutor ficou com os olhos rasos d'água. Ele disse em seguida, um pouco constrangido:

Me deu vontade de chorar porque gosto muito dessas pessoas. Sim, porque essas pessoas são os grandes intermediários, não é isso? Os protetores, porque a Mãe Aninha inventou isso [isto é, instituiu o cargo de "obá de Xangô" no Opô Afonjá, nomeando seus primeiros ocupantes] um pouco pra proteger [seu terreiro]..., [foi algo] muito bem-sucedido. Muito bem-sucedido. Se ela não tivesse feito isso, quem sabe a Mãe Stella não estava na posição em que está [quando a entrevista foi realizada Mãe Stella, hoje falecida, era a mãe de santo do Opô Afonjá, ou seja, detinha a autoridade máxima naquela comunidade], né? Porque ela conseguiu segurar o Axé Opô Afonjá fazendo essas alianças... 
A mencionada instituição dos obás de Xangô, criada por Mãe Aninha, “a figura feminina mais ilustre dos candomblés da Bahia" (Carneiro 1961:63), e Martiniano Eliseu do Bonfim, em 1937, tem diversas interpretações. Segundo Vivaldo da Costa Lima, a mãe de santo

entronizou [...] os 12 Obás de Xangô, para que os mesmos fossem o esteio da Sociedade Cruz Santa do Axé Opô Afonjá, o seu núcleo básico de suporte espiritual. Aos obás caberia também zelar pelo culto de Xangô, como os antigos ministros de Xangô nas terras iorubás cultuaram a memória de seu Alafin divinizado (Lima 2010:60-61).

Cabe dizer antes de prosseguir que, se Alafin era o título monárquico específico do governante da maior formação estatal da história iorubá, o antigo Império de Oyó (cf., e.g., Afolayan 2000), obá significa rei ou governante na língua deste povo. Acontece que, de acordo com a tradição, Xangô foi o primeiro Alafin, tendo criado também a estrutura políticoreligiosa de Oyó. Tal estrutura baseava-se na divisão de poderes entre conselhos de ministros de Estado e associações de culto. Conta-se, ademais, que apenas um desses conselhos ministeriais de Oyó, precisamente o conselho dos obás, manteve-se fiel ao fundador do império, após uma série de derrotas militares que levaram ao incêndio do palácio e ao suicídio de seu governante - o que explica a recém-mencionada referência de Vivaldo ao culto da memória de Xangô pelos obás (Lima 2010:61).

Estes enredos míticos são muito conhecidos no Brasil (cf., e.g., Prandi 2001; Verger 1981) e foi a partir deles que Mãe Aninha e Martiniano recriaram, no Opô Afonjá, esse título honorífico, integrando-o à alta hierarquia do terreiro. O corpo dos obás idealizado nos anos 30 tinha, portanto, a obrigação de manter-se fiel e de proteger os interesses do patrono da casa, Xangô Afonjá, exercendo diversas funções de suporte simbólico, jurídico e material do terreiro em face da sociedade local. Não foi à toa que depois da primeira geração de ministros do Opô Afonjá, artistas, políticos e intelectuais de renome tenham começado a aparecer em seus quadros. No contexto da pesquisa que realizei, três dos indivíduos que mais surgem nas entrevistas, nos documentos e na bibliografia consultada-Caymmi, o pintor Héctor Bernabó (Carybé) e Jorge Amado - foram obás. E Gilberto Gil é um dos atuais zeladores do culto de Xangô nesta casa de santo.

Mãe Detinha de Xangô, hoje falecida, era uma das moradoras mais antigas do Opô Afonjá quando a entrevistei. Ela devia ter uns 90 anos na época. Detinha recebeu-nos em sua própria casa, que ficava bem próxima do barracão e da habitação da mãe de santo Stella de Oxóssi. Depois de perder a sua desconfiança inicial, ela começou a contar uma série de histórias, 
esclarecendo diversas dúvidas rituais sobre a relação entre Dorival Caymmi e o terreiro. Um dos momentos mais interessantes de sua entrevista, porém, não estava relacionado com o compositor que havia falecido recentemente. Detinha fez alguns comentários a respeito da ligação nem sempre harmoniosa entre intelectuais, seus livros e o Opô Afonjá. No meio dessa fala, a idosa filha de santo conseguiu sintetizar exemplarmente a definição de segredo que permeia o candomblé, dizendo mais ou menos o seguinte: "Segredo é segredo. Não tem nada demais, não tem mistério, só tem segredo. Então, se você pega e mostra, acaba tudo".

Auô (awo) quer dizer segredo, mistério, em iorubá. Mais do que uma palavra, auô é um conceito operante nos candomblés brasileiros de todas as nações. Uma vez que o aumento de capital simbólico e mágico na hierarquia religiosa dos terreiros é diretamente proporcional à posse de conhecimentos, cuja força está associada à sua circulação restrita, ${ }^{31}$ o auô (awo) é, de acordo com um trocadilho comum nas roças de Ketu, a base do auô (áwo). Esta última palavra, quase homófona, se não fosse pelo prolongamento de sua primeira sílaba, tem uma relação semântica estreita com o segredo. Auô (áwo), enfim, significa fundamento, ou seja, os alicerces que mantêm concretamente um candomblé de pé, os objetos enterrados ali, o que embasa em profundidade o poder daquela casa e, por extensão, o próprio culto aos orixás (cf. Bastide 2001; Beniste 1997, passim). Este culto, por sua vez, tem pelo menos uma semelhança com o Caymmi assentado e silencioso que encontrei nas entrevistas que realizei e em muitas outras fontes de pesquisa.

Gilberto Gil, conforme indicado anteriormente, é o atual Obá Onikoyi do Opô Afonjá. Antes da morte de Dorival, eles parecem ter convivido por um momento no cargo: "Caymmi ainda me via, tava lá, então, éramos dois, um, éramos dois em um", disse Gil em seu depoimento. No início da sua gravação o artista fala assim do seu antecessor:

É, e lógico, sempre a lembrança daquele homem muito calmo, muito assentado, né? É, no candomblé a gente tem essa expressão de "assentar o santo", né? E o Caymmi é assim pra mim, uma pessoa completamente assentada naquele lugar da coerência absoluta, não é? Do viver em tudo, do bom e do ruim, do certo e do errado, no longe e no perto. Enfim, aquele homem certo, né? É como eu vejo.

Os versos da canção "Buda Nagô", de 1991, parecem compartilhar essa visão que seu autor tem sobre Caymmi vinte e um anos depois. Talvez encarar o adjetivo nagô do título - outro nome para a nação Ketu à qual pertencem os dois artistas - ou os dois compassos de abertura depois da anacruse $^{32}$ como uma referência à sucessão dos obás e a esse "dois, um" muito posterior seja cair "naquele lugar da coerência absoluta" dos delírios 
surrealistas ou naquilo que Clifford Geertz qualificou um dia como estória e ilusão de um paranoico (Geertz 1989:28). Talvez, tanto Geertz quanto Gil tenham razão, no entanto, em outro aspecto da questão. A intenção de Gil, na entrevista e na canção, talvez não seja mesmo fazer a "análise cultural" de qualquer sistema humano nem descrever a "existência verdadeira" das coisas (Geertz 1989), pelo contrário, ele parece empregar a sua dicção idiossincrática para poder expressar o caráter sobre-humano que ele atribui ao seu irmão de esteira. ${ }^{33}$

Tem figuras destacadas pra mim, absolutamente míticas, que passaram a existir num plano mítico, mitológico. De uma certa forma, tiveram suas qualidades humanas, pessoais etc. diluídas, quer dizer, pra dar lugar a uma, uma configuração de entidade num plano outro. E Caymmi é uma dessas figuras...

Estas duas últimas citações de Gil são trechos de uma mesma fala. Trata-se da primeira resposta do músico na entrevista que fizemos. Elas desvelam, e da forma mais explícita possível, a versão extrema, mitológica, do conjunto de personas que formam a imagem, o corpo de Dorival Caymmi. Essa entidade - um orixá, quem sabe, que talvez interceda por Gil "do alto do seu roko, a sagrada gameleira em Opô Afonjá" (Amado, J. L. 1999 [1969]:25) - é possivelmente um cruzamento de muitos dos temas transversais mencionados até aqui: a genialidade, a religiosidade e a sabedoria, no mínimo.

\section{O que não pode ser dito de nenhuma outra maneira}

\section{Coda}

Entender como atua, se manifesta e pode se expressar esse "plano outro" da diluição das "qualidades humanas" na experiência particular desse artista e nessa espécie de mitologia construída ao redor de Dorival Caymmi foi, de modo geral, um dos objetivos da minha pesquisa. Espero também ter avançado neste sentido ao longo deste ensaio.

Voltando ao depoimento do atual Obá Onikoyi do Opô Afonjá, não parece muito arriscado ver em suas declarações míticas, assim como nas antinomias de "Buda Nagô", a convivência "do bom e do ruim, do certo e do errado". Em ambos os casos é perceptível também uma utilização êmica por alguém que frequenta os candomblés do significado ritual de assentar um santo - justamente o de enterrar e alimentar os auô (áwo) individuais ou coletivos num terreiro, lessé orixá. ${ }^{34}$ 
A fala de Mãe Detinha de Xangô tem ainda um significado complementar. Nessa religião altamente hierárquica, a discrição e o silêncio parecem tornar-se não só uma ética, mas também uma educação específica (cf. Silveira 2003) da conduta, a regra implícita de qualquer interação intra e intergrupal. Mas a sua contraparte - a possiblidade eterna da circulação maldosa da fofoca, do feitiço e da suspeita (cf. Braga 1998) - também está sempre presente e talvez seja tolerada num culto que, ao que tudo indica, não recua totalmente diante da incoerência e do erro humano, "do longe e do perto" de Gil. Os próprios santos, afinal, fazem intrigas, mentem, trapaceiam e se arrependem de vez em quando (cf. Prandi 2001). Talvez Gil não quisesse dizer tanto, mas o relativo silêncio de Caymmi, seu assentamento e a rede de temas transversais e de histórias tecidas ao seu redor guardam, no mínimo, algumas analogias com tudo isso. Não se pode dizer muito mais coisas sem infringir o auô (awo) - esse segredo que, de acordo com a velha iaô, reside no ato de não contar e não na existência de qualquer conteúdo específico - nem cair de vez, de maneira ingênua e inábil, na mitologia caymmiana, diluidora das suas "qualidades humanas".

O silêncio e o auô (awo) dos candomblés de Ketu que eu encontrei em toda a minha pesquisa de doutorado pareciam conviver sempre com algo próximo da definição diametralmente oposta - mas complementar de segredo dos jongueiros que eu estudara no mestrado (Queiroz 2011). Para eles, a circulação de palavras, histórias, memórias e informações é exatamente a condição de sua força encantatória e de seu mascaramento.

Apareceram na maioria das fontes estudadas, afinal, o uso hábil das palavras, o tempero, o feitiço armado com determinadas expressões e conceitos que, se bem utilizados de modo precisamente histórico, sociológico e contextual, abririam a porta para um último paradoxo. As narrativas, mesmo as mais mirabolantes, as estórias [dos] trapaceiro[s] que Geertz não apreciava muito (Geertz 1989:28), o próprio ato de estar diante de uma plateia, de uma máquina de escrever, de um microfone ou de um entrevistador relembrando mitos e recriando fatos talvez sejam os únicos jeitos de contar e dividir experiências de outro modo incomensuráveis e inexprimíveis, como a relação entre familiares, por exemplo, e a ausência de um pai materializada num travesseiro, numa casa praticamente intocada, a admissão do corpo do "patriarca da música popular" brasileira na ilustre socialidade fúnebre do "cemitério das estrelas", os fuxicos e as insinuações, o assentamento de Caymmi, a criação de linhagens e alianças, as redes de amigos inseparáveis, os recados indiretos dados maliciosamente aos outros, as solidariedades imprevistas ou o fascínio diante de uma centena de canções. 
Em síntese e nas palavras de outro indivíduo ligado ao surrealismo, o contador de histórias Jean-Claude Carrière,

Como as minhocas que, dizem, tornam fértil a terra que atravessam às cegas, as histórias passam das bocas aos ouvidos e vêm dizendo, há muito tempo, o que não pode ser dito de nenhuma outra maneira (Carrière 2008:7).

Depois de todos esses enredos, concluo o presente artigo com a observação de que essas relações diferenciais e esses lugares-comuns não apenas fornecem a matéria-prima para a construção dos sonhos (da raça e da baianidade, por exemplo), mas também concorrem para a produção de um "outro" (de um Caymmi velho, não humano, divino, gênio, natural, primitivo, incriado etc.) amável e potencialmente perigoso.

Dorival Caymmi está, obviamente, no cruzamento dessas e de tantas outras linhas de fuga. A argumentação deste artigo tem aqui o seu ponto de chegada que bem poderia ser outro. Afinal, qualquer um dos temas coletivamente relacionados ao meu sujeito de pesquisa poderia ter sido utilizado para a visualização parcial dessa totalidade que resolvi chamar de mitologia caymmiana. Neste trabalho, contudo, privilegiei a questão racial que, espero, poderá servir como uma metáfora extraordinária de todas as outras temáticas correlatas.

A conclusão deste ensaio - stricto sensu - trata-se de uma obviedade: Caymmi não se construiu sozinho. Investigando-se a trajetória e o sucesso de um único homem é fácil acessar o pano de fundo de uma história coletiva e vice-versa. Através de uma única persona pública e do uso variado de suas diversas máscaras lendárias não nos aproximamos somente do corpo do "patriarca da música popular" brasileira. Diversos agentes, lugares, circuitos e relações também se tornam vivos e visíveis na vizinhança desses processos, dessas tramas e de todas essas entidades. ${ }^{35}$

Este imbricamento de temas e de pessoas é expressado da melhor maneira possível através de um único - e último - objeto, antevisto nas primeiras páginas deste texto. Os costumes funerários do candomblé são enriquecidos por uma pequena variação no terreiro de Dorival, o Opô Afonjá. Ao invés da destruição costumeira de todos os pertences do morto, neste terreiro o item litúrgico-individual mais importante de alguém, o otá - pedra viva que simboliza a própria pessoa de um fiel recebendo alimentos e sacrifícios regularmente - é, às vezes, preservado.

Este detalhe é seguramente uma marca de exceção - uma vez que no Opô Afonjá só se preservam os otás dos chefes de culto ou de outros homens ilustres que foram também filhos de Xangô - e, paradoxalmente, de não diferenciação. Dorival Caymmi ainda é um indivíduo, uma pessoa efetiva 
e ritualmente ativa no seu candomblé, mas a sua história, a sua trajetória individual, é por muitos acompanhada. O otá do compositor está guardado num enorme balaio, que contém também as pedras de seus irmãos notáveis dispostas misturadamente, umas sobre as outras.

Recebido em: 04 de fevereiro de 2019

Aprovado em: 09 de dezembro de 2019

Vitor Queiroz é graduado em História, Mestre em História Social da Cultura e Doutor em Antropologia Social pelo Instituto de Filosofia e Ciências Humanas da Universidade Estadual de Campinas (IFCH/ Unicamp). Dedica-se ao estudo da música popular, dos cultos afro-brasileiros e das questões étnico-raciais no Brasil por meio do cruzamento interdisciplinar entre a História Social da Cultura, a Antropologia Social e a Etnomusicologia.

https://orcid.org/0000-0003-1735-4203

E-mail: queiroz.vitor@gmail.com 


\section{Notas}

* Este artigo é resultado de uma pesquisa realizada entre 2012 e 2017 para a obtenção do título de doutor em Antropologia Social pela Universidade Estadual de Campinas. Agradeço, especialmente, à Heloísa Pontes e Luiz Gustavo Rossi, meus orientadores, aos interlocutores listados na $26^{\mathrm{a}}$ nota deste texto pela colaboração imprescindível, ao parecerista anônimo da Mana pelas valiosas sugestões e à Fundação de Amparo à Pesquisa do Estado de São Paulo (Fapesp) pelo financiamento da referida pesquisa.

1 Orin (cantiga) em iorubá (èdè Yorùbá), idioma litúrgico utilizado nos candomblés de nação Ketu (cf. Beniste 2011). Tradução livre, feita por mim. A respeito do conceito de "nação" nos contextos religiosos afro-brasileiros, cf., dentre outros, Santos (1995), Parés $(2005,2006)$ e a $30^{a}$ nota deste texto.

2 Para a concepção de trajetória, caracterizada, grosso modo, pela ancoragem social, histórica e simbólica de percursos biográfico-profissionais, cf., e.g., Sarlo (1995), Pontes (2010) e Rossi (2016).

3 Cf., a respeito, Caymmi, D. e Amado, J. (c. 1967); Barbosa e Alencar (1985); Caymmi, S. (2001, 2008, 2013); Bosco (2006); Carvalho (2010); Domingues (2009); Garcia (2013); Santanna e Leal (2015); Risério (1993) e Queiroz (2019). Além dessa bibliografia específica, Caymmi é citado em diversas obras sobre música popular brasileira como, por exemplo, Tatit (2002) e Severiano (2008).

4 Embora este texto verse sobre dois músicos conhecidos, uma discussão específica sobre a música popular produzida no Brasil foge aos seus objetivos. Indico a respeito, apenas como exemplo, a leitura de Campos (1968); Dunn e Perrone (2001); Moraes e Saliba (2010) e Sandroni (2001), além dos livros listados na nota anterior.

5 As noções de corpo, pessoa, máscara e persona utilizadas neste artigo são evidentemente devedoras das ideias de Marcel Mauss e devem ser entendidas, portanto, como fatos morais e/ou categorias do pensamento e não apenas (ou não necessariamente) como elementos biológicos. Cf. Mauss (2003, especialmente: 367-98).

6 Para maiores informações sobre Gilberto Gil (1942 - ), cf., dentre outros, Rennó (1996) e Cohn (2008).

7 Cf. Sansi (2005) e Dos Anjos (2008). Os otás ou okutás são pedras que servem de suporte para os fundamentos (áwo) que mantêm viva/em circulação a força (axé) de um fiel ou mesmo de uma divindade. Os otás, entes dotados de vida e de agência, devem ser encontrados na natureza e, após um ritual de consagração, transformam-se em verdadeiros corpos externos que personificam seres humanos e não humanos específicos. Eles devem ser ritualmente construídos ao longo dos anos, recebendo progressivamente uma série de oferendas e sacrifícios. 
8 A bibliografia sobre os diversos cultos - dentre eles, o candomblé - que são comumente reunidos e chamados de "religiões/cultos afro-brasileiras(os)", "de matriz africana", "de santo" etc. é imensa. Sugiro, apenas para situar os principais debates sobre o tema, a leitura de Santos (1995) e Parés (2005).

9 A bibliografia sobre raça e relações raciais no Brasil é particularmente extensa, tendo, ademais, desempenhado um papel fundamental na constituição do próprio campo intelectual brasileiro (especialmente na seara das Ciências Humanas), ao longo dos séculos XIX e XX. Indico, apenas a título de localização do tema, a leitura da coletânea Pinho e Sansone (2008), junto com a obra dos autores citados adiante, no tópico Silencio deste texto, e as listagens bibliográficas contidas em meus trabalhos anteriores (Queiroz 2011, 2019).

10 Caymmi, D. e Amado, J. (c. 1967:7). Tal expressão retornará ao longo deste artigo. A referência, contudo, não será indicada novamente. O mesmo valerá para os demais epítetos de Caymmi que aparecerão daqui para frente.

11 Os dados relativos ao enterro de Caymmi mencionados neste artigo podem ser vistos nas diversas reportagens on-line disponíveis sobre o tema. Duas delas, selecionadas aleatoriamente dentre muitas outras, são: "Dorival Caymmi será enterrado...", 17/08/2008, Estado de São Paulo, e "Luto sereno...", 17/08/2008, Jornal do Brasil.

12 Cf. "Você Já Foi à Bahia", samba de Caymmi gravado pelos Anjos do Inferno em 1941. Informação obtida em Severiano, Jairo; Faour, Rodrigo; Ribeiro, Sílvio e Caymmi, Stella, Discografia Essencial da Obra de Dorival Caymmi - de agora por diante apenas Discografia Essencial (Caymmi, S. 2001:604).

13 "Ai, as pratas e os ouros de Iemanjá!" é o último verso de "Morena do Mar", canção de Caymmi lançada em 1965 por Nara Leão (Discografia Essencial: 591).

14 Cf. "Saudade de Itapoan", canção praieira de Caymmi, gravada pelo próprio compositor em 1948 (Discografia Essencial: 600).

15 Moreira (2014, faixa 12).

16 Xangô (Șàngó), que também era o orixá pessoal de Caymmi, corresponde, grosso modo, ao deus dos trovões, da realeza Iorubá e consequentemente da justiça. Cf. Verger (1981) e Prandi (2001).

17 Para saber mais sobre a instituição do corpo dos obás de Xangô no terreiro do Opô Afonjá e, especificamente, sobre o cargo de Obá Onikoyi, cf. Lima (2010:5988; 139-182; 293-306; 307-314) e, principalmente, o tópico Auô adiante.

18 A Rede Globo fez diversas adaptações televisivas da obra de Jorge Amado que contaram com a música de Caymmi: Gabriela (1975), Tenda dos Milagres (1985), Tereza Batista (1992), Dona Flor e Seus 2 Maridos (1998) e Porto dos Milagres (2001). Os teledramaturgos desta empresa foram responsáveis, consequentemente, por uma parcela expressiva da divulgação e da distribuição do seu trabalho nos últimos quarenta anos, fazendo-o chegar à imensa maioria dos aparelhos televisivos do Brasil. 
19 Cf. Veloso, Caetano, Depoimento de Caetano Veloso (Caymmi, D. 1985, disco 1, faixa 8). Caetano atribui essa expressão, aliás, a João Gilberto. A frase da qual retirei a citação é a seguinte: "O João Gilberto fala sempre que o Caymmi é que é o gênio raça, né?".

20 Cf., respectivamente, e.g., Caymmi, D. T. (Dori); Caymmi, D. (Nana); Caymmi, D. (Danilo) (2013); Veloso (1972); Mello (1985); e Caymmi, D. (1972).

21 Outro verso de "Morena do Mar".

22 Por mitologia, aqui e nas próximas páginas, designo apenas um conjunto de imagens e temas inter-relacionados que costumam compor as narrativas sobre Caymmi e que apareceram repetidamente durante a minha pesquisa de campo, conforme ficará claro a seguir. Não pretendo, neste artigo, fazer uma discussão teórico-antropológica sobre o assunto.

23 Beniste (2011). Oxé (òșe), do iorubá, é o termo usado para designar um machado duplo, às vezes antropomorfo, como era o caso desta tela de Caymmi, associado ao culto do orixá Xangô.

24 Cf., em Bastide, 2001, uma descrição minuciosa da relação entre o culto público, o culto interno dos terreiros e o culto doméstico aos orixás.

25 As falas reproduzidas aqui foram ligeiramente modificadas em relação às suas transcrições ipsis verbis. Acrescentei, quando necessário, colchetes com termos de ligação e informações adicionais. Excluí também a maioria das repetições e reticências. Decidi manter, porém, estas mesmas marcas de oralidade quando elas acrescentavam nuances ou ênfases importantes ao discurso dos meus entrevistados.

26 As entrevistas realizadas para esta pesquisa foram as seguintes, em ordem cronológica: 1. Lydia Hortélio, Salvador, 01/01/2012; 2. Gilberto Gil, Rio de Janeiro, 11/04/2012; 3. Dorival Tostes Caymmi (Dori), Rio de Janeiro, 03/05/2012; 4. Danilo Tostes Caymmi, São Paulo, 23/05/2012; 5. Dinahir Caymmi, Rio de Janeiro, 16/06/2012; 6. Stella Aponte Caymmi, Rio de Janeiro, 16-17/06/2012; 7. Rosa Passos, Brasília, 14/09/2012; 8. Mãe Detinha de Xangô, Salvador, 27/10/2012; 9. Solange Carybé, Salvador, 14/01/2013; 10. Prof. Dr. Peter Fry, Rio de Janeiro, 01/05/2013; 11 . Antônio Risério, Lauro de Freitas, 25/05/2013; 12. Nancy Carybé, Salvador, 31/05/2013; 13. Prof. Dr. Robert W. Slenes, Campinas, 22/05/2014.

27 Cf. Herzfeld (2008), para uma definição do conceito de iconicidade utilizado aqui.

28 Dados retirados das duas biografias de Caymmi (Barbosa \& Alencar 1985; Caymmi, S. 2001) e de alguns documentos pessoais reproduzidos no site do Acervo Dorival Caymmi. Foram consultados o "Certificado de Reservista de 2a Categoria", Ministério da Guerra,12/02/1936; a "Certidão de Casamento de Dorival Caymmi e Adelaide Tostes", 30/04/1940 e a "Carteira Profissional" do músico, Ministério do Trabalho, Indústria e Comércio, 28/06/1944. 
29 Cf. Morais (2014, faixa 12).

30 As nações de candomblé são segmentos cultuais distintos, porém inter-relacionados, através dos quais os fiéis desta religião subdividem-se. Seus nomes derivam dos etnônimos utilizados no contexto do tráfico negreiro. A fala do meu entrevistado referia-se - assim como, aliás, todo este artigo refere-se - à nação Ketu ou Nagô, que cultua um elaborado panteão proveniente grosso modo de antigas cidades-estados Iorubás. A comunidade Ketu assumiu um caráter hegemônico no candomblé brasileiro, influenciando as demais nações (Cf., e.g., Santos 1995; Parés, 2005, 2006).

31 Cf, em Barth (2000) uma tipologia pertinente ao caso em questão, junto com uma discussão sobre as formas de aquisição de conhecimento em contextos religiosos. No artigo que intitula a coletânea, o autor enfatiza precisamente - para além da própria relação entre mestre x discípulos e iniciador x iniciados - a circulação de informações como elemento configurador das culturas e das crenças

32. Gil parece ter construído esses dois compassos a partir de: a) um salto melódico relativamente grande, uma quinta justa descendente, com repouso na subdominante ré (D), que desempenha a função de baixo ao longo da música e b) uma pausa métrica inusitada. Ambos os elementos composicionais são característicos, aliás, do samba de roda baiano e parecem separar semanticamente as sílabas da palavra ím- / par.

33 Cf. Bernabó, Hector (Carybé), Depoimento de Carybé (ciatdo em Caymmi, D. 1985, disco 1, faixa 16). Danilo Caymmi, que também é ligado ao Opô Afonjá, disse na entrevista que fizemos "frequentando o candomblé, quer dizer, nós somos irmãos de esteira". Esse parentesco religioso refere-se a seu próprio pai, Dorival. Carybé, num depoimento lançado originalmente em 1985, também utiliza a expressão para falar de seus amigos Caymmi e Jorge Amado. A expressão "irmão de esteira" faz referência, nos candomblés, a um grupo de pessoas que saíram de um mesmo "barco", que foram "feitos" em cima da mesma esteira, ou seja, que estão unidos por uma iniciação em comum. Essa locução pode marcar também o compartilhamento de um cargo na hierarquia religiosa - no caso, o dos obás de Xangô - e/ou um laço forte de amizade entre determinados membros de um terreiro.

34 Cf. Lima (2010), cujo subtítulo dá o significado da expressão, literalmente "nos pés do orixá, do santo".

35 Cf. Gell (1998) para uma definição dos conceitos de agências múltiplas e de vizinhança utilizados aqui. 


\section{Referências bibliográficas}

ACERVO DORIVAL CAYMMI. Disponível em: www.dorivalcaymmi.com.br. Acesso em 20/10/2018.

AFOLAYAN, Funso. 2000. Kingdoms of West Africa: Benin, Oyo and Asante. In: Toyin Falola (ed.), Africa-African History Before 1885. Vol. 1. Durham: Carolina Academic Press.

AMADO, James Leal. 1999 [1969]. In: GUERRA, Gregório de Matos. Crônica do viver baiano seiscentista. Rio de Janeiro: Record.

AMADO, Jorge. 1972. “Com tempo ainda curto..." (contracapa). In: D. Caymmi, Caymmi (LP), Rio de Janeiro, Odeon.

BARBOSA, Marília \& ALENCAR, Vera. 1985. Caymmi: som, imagem e magia. Rio de Janeiro/Salvador: Fundação Emílio Odebrecht/Sargaço Produções Artísticas.

BARTH, Fredrik. 2000. O Guru, o Iniciador e Outras Variações Antropológicas. Rio de Janeiro: Contra Capa.

BASTIDE, Roger. 2001 [1957]. O Candomblé da Bahia. São Paulo: Companhia das Letras.

BENISTE, José. 1997. Òrun/ Áiyé. Rio de Janeiro: Bertrand Brasil.

. 2011. Dicionário Yorubá - Português. Rio de Janeiro: Bertrand Brasil.

BOSCO, Francisco. 2006. Dorival Caymmi. São Paulo: Publifolha.

BOURDIEU, Pierre. 1998 [1986]. A Ilusão Biográfica. In: Marieta Ferreira \& Janaína Amado, Usos e Abusos da História Oral. Rio de Janeiro: FGV.

BRAGA, Júlio. 1998. O Fuxico de Candomblé. Feira de Santana: UEFS.

CAMPOS, Augusto de. 1968. Balanço da Bossa. São Paulo: Perspectiva.

CAMUS, Albert. 1997 [1978]. Diário de Viagem: a visita de Camus ao Brasil. Rio de Janeiro: Record.
CARNEIRO, Édison. 1961 [1948]. Candomblés da Bahia. Rio de Janeiro: Conquista.

CARRIÈRE, Jean-Claude. 2008 [2004]. Contos Filosóficos do Mundo Inteiro. São Paulo: Ediouro.

CARVALHO, Marielson de. 2010. Acontece Que Eu Sou Baiano: identidade e memória cultural no cancioneiro de Dorival Caymmi. Salvador: Eduneb.

CAYMMI, Dorival \& AMADO, Jorge. c. 1967 [1947]. Cancioneiro da Bahia. São Paulo: Martins.

CAYMMI, Stella. 2001. Dorival Caymmi. São Paulo: 34. . 2008. Caymmi e a Bossa Nova. Rio de Janeiro: Ibis Libris. .2013. O Que é Que a Baiana Tem? Rio de Janeiro: Civilização Brasileira. CEMITÉRIO DE SÃO JOÃO BATISTA (site oficial). Disponível em: http:// cemiteriosjb.com.br/. Acesso em 12/01/2018.

COHN, Sergio (org.). 2008. Gilberto Gil. Rio de Janeiro: Azougue.

COSTA, Sérgio. 2001. "A Mestiçagem e seus Contrários: etnicidade e nacionalidade no Brasil contemporâneo". Tempo Social, 13 (1).

DALÍ, Salvador. 1974. Sim ou A Paranoia: método crítico paranoico e outros textos. Rio de Janeiro: Artenova.

DOMINGUES, André. 2009. Caymmi sem Folclore. São Paulo: Barcarolla.

DOS ANJOS, José. 2008. "A Filosofia Política da Religiosidade Afro-Brasileira como Patrimônio Cultural Africano". Debates do NER, 9 (13).

DUNN, Christopher \& PERRONE, Charles. 2001. Brazilian Popular Music and Globalization. Nova York/ Londres: Routledge.

FREUD, Sigmund. 2001 [1900]. A Interpretação dos Sonhos. Rio de Janeiro: Imago. 
GARCIA, Walter. 2013. Melancolias, Mercadorias: Dorival Caymmi, Chico Buarque, o pregão de rua e a canção popular-comercial no Brasil. Cotia: Ateliê Editorial.

GEERTZ, Clifford. 1989 [1973]. A Interpretação das Culturas. Rio de Janeiro: LTC.

GELL, Alfred. 1998. Art and Agency. Oxford: Oxford University.

GOLDMAN, Márcio. 2009. "Histórias, Devires e Fetiches das Religiões Afro-Brasileiras". Análise Social, 44 (190). . 2012. "O Dom e a Iniciação Revisitados: o dado e o feito em religiões de matriz africana no Brasil". Mana, 18 (2).

HERZFELD, Michael. 2008 [2004]. Intimidade Cultural. Lisboa: Editorial 70.

LIMA, Vivaldo da C. 2010. Lesse Orixá: nos pés do santo. Salvador: Corrupio.

MAUSS, Marcel. 2003 [1950]. Sociologia e Antropologia. São Paulo: Cosac Naify.

MORAES, José V. \& SALIBA, Elias T. (orgs.). 2010. História e Música no Brasil. São Paulo: Alameda.

PARÉS, Luis Nicolau. 2005. The Nagôization process in Bahian candomblé. In: Toyin Falola \& Matt Childs (eds.), The Yoruba Diaspora in the Atlantic World. Bloomington/ Indianapolis: Indiana University.

. 2006. A Formação do Candomblé: história e ritual da nação jeje na Bahia. Campinas: Unicamp.

PINHO, Osmundo \& SANSONE, Lívio (orgs.). 2008. Raça: novas perspectivas antropológicas. Salvador: ABA/ Edufba.

PONTES, Heloísa. 2010. Intérpretes da Metrópole. São Paulo: Edusp.

PRANDI, Reginaldo. 2001. Mitologia dos Orixás. São Paulo: Companhia das Letras.

QUEIROZ, Vítor. 2011. Olha só, ô meu Tambú, como chora o candongueiro: as estrelas e os toques da tradição no jongo de Guaratinguetá e Campinas-SP. Dissertação de Mestrado, IFCH/Unicamp.

2019. Dorival Caymmi: a pedra que ronca no meio do mar. Rio de Janeiro: Papéis Selvagens.

RENNÓ, Carlos (org.). 1996. Gilberto Gil: todas as letras. São Paulo: Companhia das Letras.

RISÉRIO, Antônio. 1993. Caymmi: uma utopia de lugar. São Paulo/Salvador: Perspectiva/Copene.

ROSSI, Luíz G. 2016. O Intelectual Feiticeiro: Édison Carneiro e o campo de estudos das relações raciais no Brasil. Campinas: Unicamp.

SANDRONI, Carlos. 2001. Feitiço Decente: transformações do samba no Rio de Janeiro. Rio de Janeiro: Zahar.

SANSI, Roger. 2005. "The Hidden Life of Stones: historicity, materiality and value of candomblé objects in Bahia". Journal of Material Culture, 10 (2).

SANTANA, Marilda \& LEAL, Carlos (orgs.). 2015. Cem Anos de Dorival Caymmi. Salvador: Edufba.

SANTOS, Jocélio dos. 1995. O Dono da Terra: o caboclo nos candomblés da Bahia. Salvador: SarahLetras.

SANTOS, Juana dos. 1976 [1972]. O Nàgô e a Morte. Petrópolis: Vozes.

SARLO, Beatriz. 1995. Borges: un escritor en las orillas. Buenos Aires: Ariel.

SEIGEL, Micol. 2009. Uneven Encounters: making race in Brazil and the United States. Durham: Duke University.

SEVERIANO, Jairo. 2008. Uma História da Música Popular Brasileira. São Paulo: Editora 34

SILVEIRA, Marialda J. 2003. A Educação pelo Silêncio. Ilhéus: Editus.

STRATHERN, Marilyn. O Efeito Etnográfico. 2014. In: O Efeito Etnográfico e Outros Ensaios. São Paulo: Cosac Naify. 
TATIT, Luiz. 2002 [1995]. O Cancionista: composição de canções no Brasil. São Paulo: Edusp.

TURNER, Victor. 1970 [1967]. The

\section{Matérias}

"Dorival Caymmi será enterrado na tarde de hoje no Rio". 17/08/2008. O Estado de São Paulo. Disponível em: http:// cultura.estadao.com.br/noticias/ musica,dorival-caymmi-sera-enterrado-na-tarde-de-hoje-no-rio, 225587. Acesso em 10/01/2019.

"Galeria do Samba - G.R.E.S. Estação Primeira de Mangueira, Carnaval de 1986, 'Caymmi mostra ao mundo o que a Bahia tem e a Mangueira
Forest of Symbols. Ithaca: Cornell University.

VERGER, Pierre Fatumbi. 1981 [1951].

Orixás. Salvador: Corrupio. também'". Disponível em: http:// www.webcitation.org/6O8 4NXQyO. Acesso em 11/01/2019.

"Luto sereno no enterro de Dorival Caymmi". 17/08/2008. Jornal do Brasil, Rio de Janeiro. Disponível em: http://www.jb.com.br/cultura/ noticias/2008/08/17/luto-sereno-em-enterro-de-dorival-caymmi/. Acesso em 10/01/2019.

\section{Discografia}

CAYMMI, Dorival. 1972. Caymmi (LP), Rio de Janeiro, Odeon. . 1985. Caymmi: Som, Imagem e Magia (LP duplo), Rio de Janeiro/ Salvador, Odebrecht.

CAYMMI, Dorival Tostes (Dori Caymmi). 2011. Poesia Musicada (CD), Rio de Janeiro, Acari.

CAYMMI, Dorival T.; CAYMMI, Dinahir T. \& CAYMMI, Danilo. 2013. Nana, Dori e Danilo: Caymmi (CD), Som Livre.
MELLO, Augusto (prod.). 1985. Tenda dos Milagres (LP), Som Livre.

MORAIS, Leandro. 2014. Preta (CD), Brasília /Rio de Janeiro, Palavra.

MOREIRA, Gilberto Gil. 1991. Parabolicamará (LP), WEA. . 2014. Gilbertos Samba (CD), Rio de Janeiro, Geléia Geral/Sony Music.

OLIVEIRA, João Gilberto. 1959. Chega de Saudade (LP), Rio de Janeiro, Odeon.

VELOSO, Caetano. 1972. Transa (LP), Rio de Janeiro, Polygram. 
O CORPO DO PATRIARCA:

UMA ETNOGRAFIA DO SILÊNCIO, DA MORTE E DA AUSÊNCIA

\section{Resumo}

Este artigo inicia-se com uma descrição, mediada por fontes on-line, do enterro do músico Dorival Caymmi e com o relato de uma visita que fiz ao local de sua morte, um apartamento no Rio de Janeiro. Em seguida, trato de problematizar e complexificar - à luz das noções clássicas de corpo e pessoa, bem como de um aparato conceitual inspirado nas formas de conhecimento do candomblé brasileiro - a figura pública deste artista, ora subdividindo, ora multiplicando-a em entidades analíticas diversas. Apresentadas as personas de Caymmi e o que chamei de temas transversais, um conjunto de imagens criado a partir da sua trajetória, refletirei brevemente sobre uma categoria êmica, indispensável tanto para as religiões afro-brasileiras quanto para o próprio Caymmi: o silêncio. Concluo com algumas considerações a respeito dos constrangimentos necessariamente implicados nas narrativas, nas lembranças e, de um modo geral, nos testemunhos históricos. Palavras-chave: Dorival Caymmi; Noções de corpo e pessoa; Silêncio e segredo; Religiões afro-brasileiras.
THE BODY OF THE PATRIARCH: AN ETHNOGRAPHY OF SILENCE, DEATH AND ABSENCE

\section{Abstract}

This article begins with a description of Dorival Caymmi's funeral and an ethnographic description of his last place of residence, in Rio de Janeiro. Guided not only by classical notions of body and personhood, but also by concepts deriving from Brazilian candomblé, I then discuss the public image of this famous popular musician, subdividing it and multiplying it into various analytical entities. Having presented the personas and what I have called cross-cutting themes related to Caymmi's life and oeuvre, I reflect on an emic category, essential for him and Afro-Brazilian cults: silence. I conclude the article by considering a few questions usually involved in narrative settings, recollections or historical testimonies.

Key words: Dorival Caymmi; Notions of person and body; Silence and secret; Afro-Brazilian cults. 


\section{EL CUERPO DEL PATRIÁRCA: UNA ETNOGRAFÍA DEL SILENCIO, DE LA MUERTE Y DE LA AUSENCIA}

\section{Resumen}

Este artículo empieza con una descripción apoyada por fuentes online, del entierro del músico Dorival Caymmi y con el relato de una visita que hice al departamento donde él falleció, en Río de Janeiro. A continuación, problematizo y complejizo - a través de las nociones clásicas de cuerpo y de persona y, también, de un aparato conceptual inspirado en los modos de conocimiento del candomblé brasileño - su figura pública, subdividiéndola y multiplicándola en diferentes entidades analíticas. Después de haber presentado las personas de Caymmi y lo que nombré por temas transversales, un conjunto de imágenes creado a partir de su trayecto, reflexiono brevemente sobre una categoría nativa esencial para todas las religiones afro-brasileñas, así como para el propio Caymmi: el silencio. Concluyo con breves observaciones acerca de los constreñimientos implicados en los relatos, los recuerdos y los testimonios históricos en general.

Palabras clave: Dorival Caymmi; Nociones de persona y cuerpo; Silencio y secreto; Religiones afro-brasileñas. 